\title{
Zależność między leksykonem mentalnym a procesem tłumaczenia
}

\author{
Correlation between mental lexicon and translation process
}

\author{
Iwona LEGUTKO-MARSZALEK \\ Uniwersytet Gdański / University of Gdansk \\ iwona.legutko@ug.edu.pl,
}

\begin{abstract}
I have discussed cognitive aspects of translation and I have attempted to pay a particular attention to cognitive conditions guaranteeing the correct process of translation. Translating from one language into the other is, in my opinion, possible thanks to the reference to the notional ground and information processing regardless of a language. The division of one mental lexicon common for the two languages into two separate mental lexicons influences the quality of translation. The condition of a successful translation is a correct identification of the notional structure and this, in turn, is possible only after the division of the mental lexicons so that the lexical units have a direct access to beyond language notion and can activate them.
\end{abstract}

Keywords: mental lexicon, bilingualism, second language, translation process, lexical access

\section{Wstęp}

Istnieje wiele prac poświęconych tłumaczeniu z punktu widzenia językoznawstwa, a więc skupiających się na analizie struktury językowej tekstu thumaczonego. Ja chciałabym przesunąć paradygmat współczesnej translatoryki z płaszczyzny badań wyłącznie systemowych w kierunku kognitywnym i przedstawić tłumaczenie jako uwarunkowany kognitywnie proces, integrujący zarówno wiedzę językową w dwóch językach jak również niejęzykową wiedzę pojęciową. Proces tłumaczenia należy bez wątpienia do najbardziej złożonych procesów przetwarzania językowego. Już sam fakt, że proces ten integruje w sobie percepcję w jednym języku, dostęp do leksykonu mentalnego tegoż języka, uwzględnienie kontekstu sytuacyjnego, aktywację wiedzy pojęciowej, dekodowanie intencjonalnej struktury pojęciowej, zmianę kodu językowego, dostęp do leksykonu mentalnego drugiego języka oraz produkcję w tym języku, świadczy o jego złożoności. Bez współudziału tych procesów nie doszłoby do zadowalającego thumaczenia.

\section{Przetwarzanie językowe w świetle badań neurokognitywnych}

W obliczu badań prowadzonych nad mózgiem należy zaznaczyć, że przetwarzanie językowe nie odbywa się w odosobnieniu od takich procesów poznawczych jak spostrzeganie, uwaga, rozpoznawanie, zapamiętywanie i przywoływanie informacji, myślenie i rozwiązywanie problemów. Podczas gdy jeszcze do niedawna uważano, że 
jasno sprecyzowane regiony mózgu przetwarzają informacje językowe, badania za pomocą nowoczesnych metod neurofizjologicznych pokazują, że takiego uproszczonego sposobu widzenia nie da się podtrzymać. Podczas przetwarzania językowego mamy do czynienia z rozproszoną aktywnością sieci neuronowej, przy czym rola strukturalnych i funkcjonalnych połączeń między poszczególnymi częściami mózgu jest dużo bardziej znacząca niż wcześniej przypuszczano. Ten fakt stawia duże wymagania wobec nowych modeli neurokognitywnych dotyczących przetwarzania językowego. Obecnie nie jest znany żaden model uwzględniający zarówno aspekty kognitywne jak i językowe. Mamy jedynie modele, które koncentrują się na poszczególnych fazach przetwarzania językowego, a ich wyniki nie zawsze są zgodne.

$\mathrm{Z}$ badań przeprowadzanych nowoczesnymi metodami obrazowania, wynika, że obok klasycznych ośrodków mowy w przetwarzaniu językowym uczestniczy wiele korowych i podkorowych części mózgu (np. J.R. Binder i in. 1997; A.D. Friederici 2002; L.A. Stowe i in. 2005; F. Pulvermüller / L. Fadiga 2010). Pewne jest, że ośrodek Broci uczestniczy nie tylko w produkcji językowej, ale również w percepcji i pełni funkcję koordynującą w odniesieniu do procesów sensorycznych i semantycznych, które przebiegają raczej w części skroniowo-ciemieniowej (J.R. Binder i in. 1997; L.A. Stowe i in. 2005). Istotne jest również, że obszary Broci i Wernickego nie są homogenicznymi częściami mózgu, a wręcz przeciwnie, udowodniony został podział funkcjonalny. I tak okazało się, że obszar Broci (Pars opercularis, BA 44) jest również aktywny podczas przetwarzania informacji fonologicznych, leksykalnych oraz gramatycznych (np. A.D. Friederici i in. 2006; N.T. Sahin i in. 2009; S.D. Newman i in. 2003). Ta część mózgu jest także aktywna podczas przetwarzania muzyki (B. Maess i in. 2001; D. Sammler i in. 2009) oraz w procesach pamięciowych (pamięć robocza). Można wyciągnąć wniosek, że obszar Broci kontroluje sekwencje czasowe i służy analizie hierarchicznie zorganizowanych procesów (motorycznych i językowych), które leżą u podstaw wielu operacji kognitywnych. Im więcej udziału kognitywnych struktur wymaga przetwarzanie, tym większa aktywacja obszaru Broci. Ta część mózgu stanowi ważny funkcjonalnie węzeł podzielonego układu nerwowego i posiada funkcje regulujące i integrujące aktywność dotyczącą procesów poznawczych. Obszar Wernickego jest wprawdzie odpowiedzialny za audytywne przetwarzanie głosek i dźwięków, jednak to właśnie graniczące ze sobą skroniowo-ciemieniowe rejony mózgu (Gyrus angularis, Gyrus temporalis medius i inferior) uczestniczą w szczegółowej analizie semantyczno-lingwistycznej. I tak - górny, środkowy i dolny obszar płata skroniowego, jak i dolna część płata ciemieniowego są istotne dla rozumienia języka i budowania znaczenia (np. J.R. Binder i in. 1997; L.A. Stowe i in. 2005). Gyrus supramarginalis, który odpowiedzialny jest za percepcję językową, aktywny jest również podczas przetwarzania intonacji i prawdopodobnie bierze udział w procesach pamięci roboczej dotyczącej bodźców audytywnych (J.R. Binder i in. 1997). Z tego powodu nie można go zakwalifikować jako obszar przetwarzający jedynie informacje językowe. Gyrus angularis jest z kolei nie tylko odpowiedzialny za rozpoznawanie formy słów, lecz stanowi obszar przetwarzający różnego typu informacje i odpowiada ogólnie za asocjacje semantyczne (C.J. Price 2000). Udział prawej półkuli w analizie informacji prozodycznych, kontekstu, przetwarzaniu języka symbolicznego i metafor 
jak i w tworzeniu inferencji nie podlega obecnie dyskusji (np. G. Bottini i in. 1994; M. St. George i in. 1999; S. Coulson/ C. van Petten 2002; S. Coulson/ C. Lovett 2004; A.D. Friederici/ K. Alter 2004; G.L. Schmidt/ C.A. Seger 2009; A.B. Cieślicka/ R.R. Heredia 2011).W procesach przetwarzania językowego została na domiar tego udowodniona również rola móżdżku oraz głębiej położonych struktur mózgu, jak struktury podkorowe, tzw. jądra podstawy (basal ganglia), wyspa (insula) i wzgórze (thalamus) (np. M.D. Johnson/ G.A. Ojemann 2000; C.W. Wallesch 2006; M.T. Ullman 2006; J.R. Booth i in. 2007; H. Ackermann 2008; M. Wahl i in. 2008; S.A. Kotz i in. 2009).

Dzięki licznym, przeprowadzonym eksperymentom mogły powstać bardziej szczegółowe modele dotyczące procesów związanych z przetwarzaniem językowym (G. Rickheit i in. 2010; F. Rösler 2011). Wykazano też, że wiedza pojęciowa dotycząca obiektów reprezentowana jest w różnych sieciach neuronowych mózgu i w zależności od potrzeby i zadania aktywowane są odpowiednie neurony (np. H. Damasio $\mathrm{i}$ in. 2004). Aktualne modele neurokognitywne podkreślają znaczenie czasu w procesach językowych (wyniki badań potencjałów wywołanych metodą EEG lub MEG pokazują czasowe sekwencje procesów zachodzących w mózgu) i próbują pogodzić te wyniki z wynikami dotyczącymi lokalizacji aktywności mózgu (wyniki badań przeprowadzonych metodą obrazowania PET lub fMRI umożliwiają dokładną lokalizację aktywności mózgu). Aby stworzyć obszerny model obejmujący wszystkie procesy językowe, nie wystarczy niestety samo uwzględnienie lokalizacji czy sekwencji czasowej aktywności mózgu. Można to zaobserwować, kiedy bada się np. zaburzenia mowy (afazje), które wystąpiły na skutek uszkodzenia mózgu już po opanowaniu języka (C.K. Thompson i in. 2010). Przy tego typu zaburzeniach widoczne jest ogromne zróżnicowanie w symptomach, co stanowi wyzwanie dla neurobiologicznych modeli językowych. Przykładowo jeśli wystąpi uszkodzenie mózgu w obszarze Broci, to jedynie u $85 \%$ osób będą widoczne zaburzenia językowe z typowymi symptomami. Można wobec tego zauważyć, że nie da się bezpośrednio przyporządkować funkcji do struktury, ponieważ praca mózgu polega na współdziałaniu układu nerwowego. Wyniki badań zaburzeń językowych stanowią podwaliny dla teorii lingwistycznych i modeli w odniesieniu do neurobiologicznej rzeczywistości. Istotną rzeczą dla osadzonego w biologii modelu językowego jest więc uwzględnienie badań dotyczących strukturalnych i funkcjonalnych połączeń nerwowych różnych obszarów mózgu. Język nie może być dłużej postrzegany jako odrębny moduł w mózgu a zdolność językowa nie powinna być rozumiana jako odizolowana i wyróżniająca się osobliwość umysłu, lecz jako poziom osiągniętej sprawności umożliwiający komunikację, która zakorzeniona jest $\mathrm{w}$ ludzkim poznaniu.

Heterogeniczność dotychczasowych wyników badań spowodowana była niedostateczną wiedzą na temat leżących u podstaw zachodzących w mózgu procesów zależności neuroanatomicznych. Nauka jest jeszcze bardzo oddalona od tego, aby zg łębiać językowe procesy przetwarzania i sposób organizacji leksykonu mentalnego. Wyniki badań pozwalają jedynie na przypuszczenie, jak kompleksowym procesem jest przetwarzanie językowe. Proces tłumaczenia, który absorbuje wiele części mó- 
zgu, jest jeszcze bardziej skomplikowany, ponieważ przetwarzanie bazuje na przynajmniej dwóch systemach językowych. Metody obrazowania mózgu nie są jeszcze tak zaawansowane, aby jednoznacznie i precyzyjnie identyfikować procesy zachodzące w mózgu. Obecna technika nie pozwala na opracowywanie sygnałów przepływu krwi, które dotyczą dziesiątek milimetrów sześciennych tkanki mózgu. Dlatego nie pozostaje nam nic innego, jak zadowolić się licznymi modelami, które próbują przybliżyć procesy przetwarzania językowego w mózgu.

\section{Kognitywne aspekty procesu tlumaczenia}

W niniejszym artykule chciałabym zwrócić uwagę na jeden z procesów przetwarzania językowego, jakim jest tłumaczenie z jednego języka na drugi, a dokładniej na zależność między jakością tłumaczenia a leksykonem mentalnym. Obecny stan rozwoju techniki niestety nie pozwala jeszcze na obserwację przebiegu kompleksowych procesów przetwarzania językowego w ten sposób, aby je oddzielić od siebie, jednoznacznie zidentyfikować i zlokalizować. Dlatego jest tak dużo niezgodności, niejasności i niedociągnięć w wynikach eksperymentalnych. Nie można bowiem pominąć faktu, że w przetwarzaniu językowym bierze udział wiele różnych struktur mózgowych, które składają się z ogromnej liczby połączeń neuronowych a sam proces tłumaczenia zależy od prawidłowo funkcjonującego mózgu, poznawczej zdolności przetwarzania informacji, wyśmienitej kompetencji językowej i komunikatywnej w przynajmniej dwóch językach, wiedzy lingwistycznej, oddzielnych leksykonów mentalnych, wiedzy ogólnej względnie specjalistycznej, wiedzy dotyczącej teorii tłumaczenia, zdolności tłumaczeniowej i wyćwiczonej umiejętności tłumaczenia. Istotną rolę odgrywa tutaj aktywowany w procesie tłumaczenia leksykon mentalny, w którym zapisane są wszystkie jednostki leksykalne przyswojonego języka wraz z informacjami językowymi charakteryzującymi te jednostki. Podczas przetwarzania językowego oprócz leksykonu mentalnego aktywowane są również inne komponenty pamięci dotyczące zarówno wiedzy ogólnej jak i językowej czy zastosowania reguł gramatycznych (I. Legutko-Marszałek 2016: 165-167).

Odniesienie się do struktury pojęciowej i przetwarzanie na płaszczyźnie pozajęzykowej warunkuje prawidłowe tłumaczenie. Jednak, aby mogło do tego dojść, osoba tłumacząca musi moim zdaniem dysponować oddzielnymi leksykonami mentalnymi, tak aby jednostki leksykalne języka ojczystego (L1) zapisane były w jednym leksykonie, a jednostki języka obcego (L2) w drugim. Jednostki leksykalne L1 i L2 powinny mieć bezpośredni dostęp do wspólnego systemu pojęć, tak żeby mogły aktywować nie tylko jednostki leksykalne drugiego języka ale i pojęcia. Należy przy tym rozróżnić pomiędzy znaczeniem jako reprezentacją semantyczną zależną od języka a niejęzykowym pojęciem jako reprezentacją wiedzy, a tym samym pomiędzy językową i pozajęzykową płaszczyzną przetwarzania (I. Legutko-Marszałek 2007a). Leksykon mentalny jest natomiast jedną z części pamięci długotrwałej, która jest powiązana z deklaratywnymi i proceduralnymi strukturami wiedzy (I. Legutko-Marszałek 2016: 105, rys. 7). Jednostka leksykalna stanowi reprezentację zawierającą wszystkie informacje językowe, które są automatycznie aktywowane wraz z daną jednostką lek- 
sykalną. W procesie przetwarzania językowego następuje aktywacja jednostek leksykalnych w leksykonie mentalnym, które podlegają analizie preleksykalnej, tzn. rozkładane są na pojedyncze litery i głoski w zależności od tego czy mamy do czynienia z procesami pisania i czytania czy mówienia i słuchania.

Aby mogło dojść do procesu translacji osoba tłumacząca musi znać przynajmniej dwa języki. Informacje odbierane w jednym języku muszą być najpierw właściwie zrozumiane, a następnie odpowiednio wiernie odtworzone w drugim języku. W procesie tłumaczenia mamy do czynienia ze złożoną czynnością kognitywną, podczas której dochodzi do zrozumienia tekstu wyjściowego uwzględniając wewnętrzne i zewnętrzne czynniki, a następnie odtworzenia go stosując reguły innego systemu językowego. Proces tłumaczenia zachodzi między percepcją w jednym języku a produkcją w innym. Tego typu procesy rzadko przebiegają rutynowo. Przebieg subiektywnego rozumienia nie zawsze odbywa się automatycznie. Tłumacz musi często świadomie konstruować sceny, sprawdzać niekontrolowane sformułowania w języku docelowym oraz upewnić się, czy dysponuje odpowiednią wiedzą. Automatyczne i nieświadome przetwarzanie informacji jak spostrzeganie, dostęp do leksykonu mentalnego, aktywacja asocjacyjnych powiązań, poprawna budowa zdań itp. przebiega w zasadzie szybko i paralelnie. Kontrolowane i świadomie zainicjowane przetwarzanie informacji typu koncentracja, przypominanie, korygowanie błędów itp. przebiega natomiast powoli i po kolei (V. Gadenne 1996: 107ff.). W procesie produkcji językowej podstawą są świadome procesy. Są one kontrolowane przez regulację metakognitywną, czyli monitorowanie wiedzy na temat własnych zdolności poznawczych i deficytów. Dlatego w danej sytuacji można celowo zastosować strategie, które sterują kognitywnym zachowaniem (S. Kupsch-Losereit 1997). Proces tłumaczenia wymaga od thumacza wiedzy ogólnej, bazującej na doświadczeniach i kulturze obszaru językowego, a czasami nawet wiedzy specjalistycznej.

W zależności od tego, w którym kierunku przebiega tłumaczenie, następuje aktywacja leksykonu mentalnego najpierw pierwszego języka, a następnie drugiego lub odwrotnie. Proces tłumaczenia rozpoczyna percepcja językowa. Zrozumienie zawartych w tekście treści jest procesem zależnym od języka, wiedzy i kontekstu. Przetwarzanie językowe jest wobec tego nie tylko analizą informacji wejściowych, ale aktywnym konstruowaniem reprezentacji mentalnej bazującej na wiedzy, która nie koniecznie była zawarta w danych wejściowych. Integralną częścią składową przetwarzania językowego są wobec tego inferencje, które łączą treści tekstu z wiedzą dotyczącą faktów i doświadczeń, aktów mowy, interakcji w taki sposób, aby sens tekstu był dobrze zrozumiany (G. Rickhei/ H. Strohner 1999). Rozumienie powinno więc być traktowane jako rezultat procesów poznawczych, na które składają się między innymi wnioskowanie i rozwiązywanie problemów.

Jak widać na przedstawionym poniżej modelu, w procesie translacji chodzi o to, aby treść zawarta w tekście była przeniesiona z jednego języka (L1) na drugi (L2) w możliwie wierny i zrozumiały dla odbiorcy sposób. Aby prawidłowo rozszyfrować pozajęzykową strukturę pojęciową, tłumaczony tekst musi być najpierw podzielony, a mniejsze jednostki tłumaczeniowe takie jak zdania, części zdań, frazy a nawet pojedyncze słowa muszą być dokładnie przeanalizowane. Proces tłumaczenia rozpoczyna 
się przetwarzaniem fonetyczno-fonologicznym. W czasie słuchania akustyczna sekwencja dźwięków, a podczas czytania wizualna sekwencja znaków graficznych jest rejestrowana i poddawana analizie preleksykalnej, w następstwie czego dochodzi do identyfikacji głosek i liter języka wyjściowego.

akustyczna percepcja dźwięków w L1 /

wizualna percepcja znaków graficznych L1

przetwarzanie fonologiczne

aktywacja i selekcja jednostek leksykalnych wraz z informacjami fonetycznofonologicznymi, morfologicznymi, semantycznymi, syntaktycznymi i pragmatycznymi dostęp do leksykonu mentalnego L1

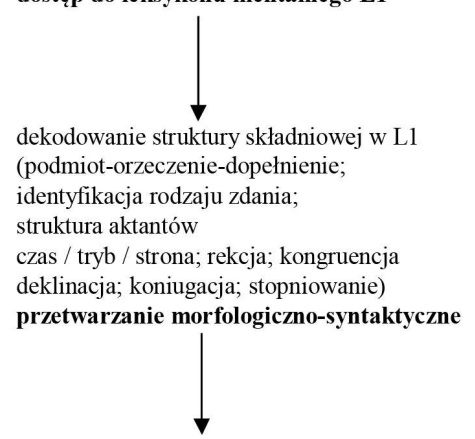

dekodowanie struktury semantycznej w L1 przez zintegrowanie aktywowanych znaczeń jednostek leksykalnych identyfikacja ról tematycznych przetwarzanie semantyczne

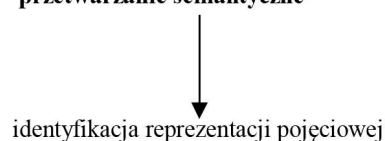

intencjonalnej treści wypowiedzi

pozajęzykowe przetwarzanie konceptualne

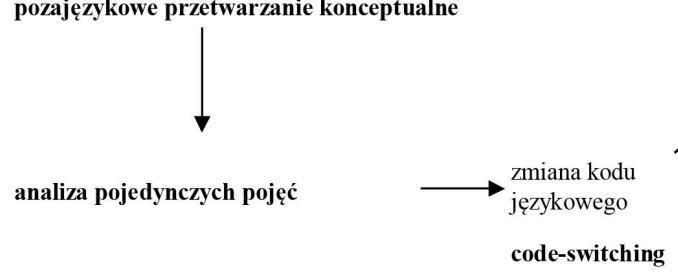

artykulacja w L2 /

kodowanie graficznych znaków w L2

przetwarzanie fonologiczne

rozłożenie jednostek leksykalnych L2 na

pojedyncze głoski lub litery

planowanie motoryki

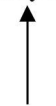

kodowanie struktury syntaktycznej w L2

automatyczna

aktywacja

ekwiwalentów L2

przetwarzanie morfologiczno-syntaktyczne

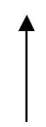

kodowanie struktury semantycznej w L2 i

przypisanie ról tematycznych

przetwarzanie semantyczne

przetwarzanie sema

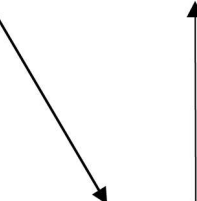

aktywacja leksykonu mentalnego L2 i wybór jednostek leksykalnych wraz z informacjami fonetyczno-fonologicznymi, morfologicznymi, semantycznymi, syntaktycznymi i pragmatycznymi, odpowiadających zidentyfikowanym pojęciom

weryfikacja (akceptacja lub korekta) i porównanie automatycznie aktywowanych ekwiwalentów L2 z pojęciami dostęp do jednostek leksykalnych L2

Rys. 1. Przebieg procesu tłumaczenia (I. Legutko-Marszałek 2016: 185).

Ta faza przetwarzania językowego sterowana jest przez pamięć roboczą, czyli centralny ośrodek przetwarzania informacji, który czuwa i kontroluje wszystkie wcho- 
dzące i wychodzące informacje. Sensoryczna informacja wejściowa aktywuje leksykon mentalny L1, w którym następnie dochodzi do rozproszonej aktywacji w poszukiwaniu jednostki leksykalnej odpowiadającej formie informacji wejściowej. Z ilości aktywowanych jednostek leksykalnych te zostaną rozpoznane i wybrane, które najbardziej pasują do informacji wejściowej. Po wybraniu odpowiednich jednostek, pozostałe jednostki pozostające z nimi w relacji, są dezaktywowane. Wraz z dostępem do leksykonu mentalnego i wyborem właściwych jednostek leksykalnych w L1, aktywowane są automatycznie wszystkie informacje językowe charakteryzujące te jednostki. Informacje językowe integrowane są w ramach całościowej struktury językowej. Przywołanie informacji syntaktycznej charakteryzującej części zdania czy ilość miejsc, które otwiera dana jednostka, umożliwia określenie struktury syntaktycznej. Przy tym następuje identyfikacja takich parametrów, jak rodzaj zdania, czas, strona i tryb. Dekodowanie struktury morfologiczno-syntaktycznej wymaga nie tylko aktywacji pamięci deklaratywnej, gdzie zmagazynowana jest wiedza dotycząca gramatyki języka, w którym został napisany tekst, lecz także pamięci proceduralnej, gdzie zapisane są wzory stosowania reguł gramatycznych. Prawie równocześnie z minimalnym tylko opóźnieniem (A.D. Friederici/ S.A. Kotz 2003) identyfikowane są role tematyczne, a następnie cała struktura semantyczna. Znaczenia językowe aktywują przy tym odpowiadające im reprezentacje wiedzy w postaci pojęć i w ten sposób dochodzi do identyfikacji konceptualnej struktury pozajęzykowej. Konkretne słowa aktywują dodatkowo reprezentację obrazową. Wpływ na interpretację struktury pojęciowej ma również kontekst sytuacyjny, który modyfikuje i pozwala jednoznacznie zinterpretować wieloznaczne znaczenia. Odbiorca tekstu rekonstruuje relacje między reprezentacjami konceptualnymi przedstawionymi w tekście sięgając do wiedzy zgromadzonej w pamięci długotrwałej i aktywując odpowiednie modele mentalne.

Po aktywacji odpowiadających znaczeniom językowym pojęć i zidentyfikowaniu struktury konceptualnej, można rozpocząć tłumaczenie na drugi język. Podczas gdy proces produkcji językowej zaczyna się od konstruowania kognitywnej reprezentacji wyrażającej intencje nadawcy, to w procesie translacji struktura pojęciowa jest już zawarta w tłumaczonym tekście, musi tylko być prawidłowo zinterpretowana i odtworzona za pomocą środków językowych L2. Aby powstał ekwiwalentny tekst w L2, musi nastąpić przełączenie z jednego systemu językowego na drugi. Ten proces wymaga aktywacji leksykonu mentalnego języka, na który dany tekst ma być przetłumaczony. Podczas aktywacji leksykonu mentalnego L2 następuje wybór odpowiadających pozajęzykowym pojęciom jednostek leksykalnych i porównanie ich z paralelnie aktywowanymi jednostkami L1. W procesie percepcji językowej aktywowane są bowiem nie tylko charakteryzujące daną jednostkę leksykalną informacje językowe, ale również inne powiązane z nią asocjacyjnie jednostki leksykalne, a wśród nich ekwiwalenty L2. Jeśli automatycznie aktywowany ekwiwalent L2 odpowiada wyobrażeniu pojęcia, jest akceptowany. W przypadku niezgodności następuje korekta i przeszukanie leksykonu za inną odpowiadającą pojęciu jednostką leksykalną. Z leksykonu mentalnego L2 selekcjonowane są tylko te jednostki leksykalne, które odpowiadają strukturze pojęciowej. Inne aktywowane automatycznie jednostki są dezaktywowane. 
Dostęp do jednostki leksykalnej języka docelowego może przebiegać w dwojaki sposób, tzn. poprzez odniesienie się do pojęcia lub bezpośrednio. W procesie tłumaczenia wraz z identyfikacją jednostki leksykalnej aktywowana jest bowiem również reprezentacja pojęciowa, która następnie musi być wyrażona przez jednostkę innego języka. Może się jednak zdarzyć, że system pojęciowy nie dysponuje tego rodzaju reprezentacją, i trzeba znaleźć odpowiedni ekwiwalent w L2 bez odniesienia się do pozajęzykowej reprezentacji wiedzy. Jako przykład może posłużyć tutaj tłumaczenie tekstów specjalistycznych, w których dominuje terminologia fachowa, która ma zazwyczaj dokładne ekwiwalenty w innych językach (tzw. całkowita ekwiwalencja). W takiej sytuacji możliwe jest prawidłowe oddanie znaczenia językowego w L2, mimo że nie dysponuje się danym konceptem, np. szelf-Schelf, korozja - Korrosion, tektoniczny - tektonisch, żółtaczka - Hepatitis, piramida - Pyramide, tlen - Oxygen, węglowodany - Kohlenhydrate, emancypować - emanzipieren itp.

Po weryfikacji, czy automatycznie aktywowane ekwiwalenty odpowiadają pojęciom, następuje faza leksykalizacji. Uwzględniając aktywowane wraz z jednostką leksykalną informacje językowe następuje przypisanie funkcji semantycznych (ról tematycznych) i zbudowanie struktury syntaktycznej odpowiadającej zasadom gramatycznym języka, na który dany tekst jest tłumaczony. W procesie translacji należy zwrócić uwagę na to, czy rodzaj, czas, strona i tryb tworzonego zdania nie naruszają treści oryginału. Walencja czasownika języka docelowego otwiera obligatoryjne i fakultatywne miejsca, które są uzupełniane przez aktanty. Struktura podmiot-orzeczenie-dopełnienie reguluje rekcję czasownika i zgodność w liczbie i osobie, co umożliwia uporządkowanie w odpowiedniej kolejności aktywowanych jednostek. Po ustaleniu struktury syntaktycznej następuje planowanie motoryki. Do tego potrzebne jest rozłożenie jednostek leksykalnych na pojedyncze dźwięki lub litery i przygotowanie do artykulacji względnie kodowania graficznego. Wynikiem procesu planowania jest informacja wyjściowa w postaci mówienia lub pisania. Informacje motoryczne nadzorowane są przez pamięć roboczą, tak aby niepoprawne wyrażenia były natychmiast korygowane. Kontekst sytuacyjny, wiedza inferencyjna jak i struktury proceduralne wpływają cały czas na przebieg procesu tłumaczenia. W ten sposób przebiega tłumaczenie całego tekstu. Prawidłowe zrozumienie i oddanie treści tekstu w innym języku sprawiają znaczne trudności. Dlatego tak istotna jest właściwa interpretacja struktury pojęciowej.

Jeśli rozważamy kognitywne aspekty procesu tłumaczenia, trzeba być świadomym jednej rzeczy, a mianowicie, że proces translacji obejmuje nie tylko przetwarzanie językowe, lecz także przetwarzanie na pozajęzykowej płaszczyźnie pojęciowej. Celem udanego tłumaczenia jest przede wszystkim zrekonstruowanie struktury pojęciowej na podstawie informacji niesionych przez jednostki leksykalne L1, która następnie ma być możliwie wiernie odtworzona w L2. Wraz z dostępem do leksykonu mentalnego i aktywacją jednostek leksykalnych proces ten odbywa się na płaszczyźnie językowej. Odniesienie się do pojęciowych reprezentacji wiedzy jest równoznaczne z operowaniem na pozajęzykowych strukturach konceptualnych. Przy tym aktywowane są deklaratywne i proceduralne komponenty pamięci, w których zmaga- 
zynowane są reprezentacje dotyczące wiedzy i sekwencji działań. Sam proces thumaczenia należy scharakteryzować jako paralelny i o rozproszonej aktywacji. Wprawdzie percepcja językowa w L1 rozpoczyna się dekodowaniem struktury fonetycznofonologicznej i analizą preleksykalną, jednak zaraz aktywowany jest leksykon mentalny, wiedza językowa i pozajęzykowa, dzięki czemu możliwe jest przetwarzanie syntaktyczne i semantyczne oraz określenie struktury pojęciowej (I. Legutko-Marszałek 2016: 167, rys.10). Po identyfikacji struktury pojęciowej następuje przełączenie na drugi język. W procesie produkcji językowej w L2 mamy do czynienia najpierw z przetwarzaniem semantycznym a następnie syntaktycznym i na końcu tego procesu następuje kodowanie fonetyczno-fonologiczne (I. Legutko-Marszałek 2016: 165, rys. 9). Kierunek tego procesu ma wpływ na kolejność aktywowania informacji językowych. Podczas gdy w procesie percepcji językowej dostęp do jednostek leksykalnych następuje za pośrednictwem formy słowa, to w procesie produkcji językowej dostęp następuje przez znaczenie słowa.

\section{Rola leksykonu mentalnego $\mathrm{w}$ procesie tlumaczenia}

Tłumaczenie $\mathrm{z}$ jednego języka na drugi jest według mnie możliwe dzięki zdolności odnoszenia się do płaszczyzny pojęciowej i przetwarzania informacji niezależnie od języka. Cały proces thumaczenia musi oczywiście być monitorowany i kontrolowany tak, aby niepoprawne gramatycznie konstrukcje mogły być od razu korygowane. Nie zawsze jesteśmy świadomi procesów zachodzących w naszym mózgu, ponieważ są one częściowo zautomatyzowane i bardzo szybkie - jak w przypadku produkcji i percepcji językowej, albo są perfekcyjnie wyćwiczone, tak że nie sprawiają większych problemów - jak w przypadku tłumaczenia. Dopiero, gdy napotkamy jakieś trudności lub próbujemy je wyjaśnić, zastanawiamy się nad nimi. Kompetencja tłumaczeniowa jest czymś więcej niż tylko bardzo dobrze opanowaną umiejętnością, a mianowicie jest pewną zdolnością balansowania między dwoma systemami językowymi. O tym, że nie każdy dysponuje taką zdolnością, świadczą liczne nieudane tłumaczenia. Istotną część stanowią w tym kontekście dwa oddzielne leksykony mentalne, które zawierają jednostki leksykalne danego języka w postaci reprezentacji umożliwiającej dostęp do wszystkich informacji językowych charakteryzujących daną jednostkę. W procesach przetwarzania językowego musi nastąpić aktywacja jednostek leksykalnych w leksykonie mentalnym, aby wypowiedź została zrozumiana a struktura pojęciowa prawidłowo zinterpretowana. Dostęp do leksykonu mentalnego charakteryzuje duża interaktywność.

Wraz z wyborem jednostek leksykalnych aktywowane są równocześnie nie tylko informacje fonetyczno-fonologiczne, grafemiczne, morfologiczne, syntaktyczne, semantyczne i pragmatyczne, lecz również powiązane asocjacyjnie z tymi jednostkami synonimy, antonimy, hiperonimy, hiponimy, słowa o podobnym brzmieniu i wyglądzie, ekwiwalenty w innym języku, kolokacje, złożenia oraz inne jednostki należące do tej samej rodziny wyrazów (I. Legutko-Marszałek 2016: 90, rys. 5). Nie należy jednak mylić aktywacji na przykład informacji fonologicznej z przetwarzaniem fonologicznym. Informacja fonologiczna jest bowiem zawsze związana z konkretną jed- 
nostką leksykalną, natomiast przetwarzanie fonologiczne dotyczy całego systemu fonologicznego danego języka. Dlatego też przetwarzanie fonologiczne, morfologiczne, semantyczne czy syntaktyczne może aktywować inne struktury mózgu niż informacja fonologiczna, morfologiczna, semantyczna czy syntaktyczna powiązana z jednostką leksykalną, co tłumaczy wiele niezgodności w wynikach eksperymentów neurobiologicznych. Jak już wcześniej wspomniałam, poszczególne procesy zachodzące podczas tłumaczenia przebiegają na płaszczyźnie językowej i pozajęzykowej. Dla mnie znaczenie językowe, które należy rozumieć jako zdefiniowaną i umowną reprezentację semantyczną, nie jest tożsame z pojęciem, które jest pewnym konstruktem umysłowym, wyobrażeniem charakteryzującym się poszczególnymi cechami i indywidualnymi różnicami istniejącymi niezależnie od tego, czy zna się jakiś język, czy nie. Znaczenia tworzą większe struktury, określane jako propozycje, a pojęcia tworzą struktury pojęciowe zwane modelami mentalnymi. Przetwarzanie językowe przebiega oczywiście nie tylko na linii dół-góra (bottom-up), lecz również na linii góra-dół (topdown). Informacje wejściowe nie są analizowane osobno, tylko w relacji do innych jednostek, tak że jeśli chodzi o proces tłumaczenia, można mówić o zależnym od kontekstu przetwarzaniu językowym.

To, że jakość tłumaczenia zależy od prawidłowego zidentyfikowania struktury pojęciowej, nie jest czymś nowym. Nie wiadomo jednak, co powoduje, że proces tłumaczenia przebiega tak różnie w zależności od stopnia zaawansowania. Stwierdzenie, że zależy to od kompetencji językowej, jest za bardzo ogólne i nie tłumaczy mechanizmów wpływających na ten stan rzeczy. Według mnie o kompetencji językowej świadczy w dużej mierze stopień uniezależnienia się języka obcego od języka rodzimego. Wyznacznikiem tego jest właśnie bezpośredni dostęp jednostek leksykalnych języka drugiego do systemu pojęć. Jeśli język obcy nie jest opanowany bardzo dobrze, to zdania tłumaczone są zazwyczaj dosłownie, tak że czasami całość nie ma sensu. Ma to według mnie związek z tym, że jednostki leksykalne L2 są wprost zastępowane automatycznie aktywowanymi ekwiwalentami L1, ponieważ są ze sobą silnie powiązane we wspólnym leksykonie mentalnym. W początkowej fazie nauki języka drugiego pojęcia aktywowane są za pośrednictwem języka pierwszego. U uczącego się nie został jeszcze wykształcony bezpośredni dostęp języka drugiego do reprezentacji wiedzy i dlatego uczący się popełnia wiele błędów związanych ze strukturą gramatyczną języka pierwszego. Po kilku latach intensywnej nauki języka następuje rozdzielenie się wspólnego dla obu języków leksykonu i wykształcenie się dwóch odrębnych systemów, które zaczynają niezależnie funkcjonować (I. Legutko-Marszałek 2006). Jednostki leksykalne L2 uzyskują bezpośredni dostęp do systemu pojęć, tak że przetwarzanie może wyjść poza płaszczyznę językową. Z tego wynika, że kompetencja językowa gwarantująca prawidłowe tłumaczenie jest silnie związana z organizacją leksykonów mentalnych obu języków.

\section{Badanie interpretacji struktury pojęciowej w procesie thumaczenia}

Skoro warunkiem dobrego tłumaczenia jest prawidłowa interpretacja struktury pojęciowej, a zakładam, że zależy to od tego, czy wykształciły się dla obu systemów językowych oddzielne leksykony mentalne z bezpośrednim dostępem do wspólnego 
systemu pojęć, to studenci germanistyki pierwszego roku, którzy jeszcze dysponują jednym wspólnym dla obu języków leksykonem mentalnym, powinni często naruszać strukturę pojęciową w tłumaczonym tekście, natomiast studenci piątego roku, u których już nastąpiło rozdzielenie leksykonów, powinni dobrze sobie radzić z odtworzeniem struktury pojęciowej. Aby to sprawdzić, przeprowadziłam eksperyment z udziałem studentów germanistyki (I. Legutko-Marszałek 2016). W badaniu wzięły udział osoby, które rozpoczęły naukę języka drugiego po przyswojeniu języka pierwszego, opanowały go jednak w takim stopniu, że potrafią się bez problemu komunikować stosownie do sytuacji i według potrzeby przełączać się z jednego języka na drugi. Należy zaznaczyć, że studenci germanistyki podczas studiów kształtują dodatkową umiejętność, a mianowicie kompetencję tłumaczeniową. Z uwagi na to, że opanowali język obcy w wysokim stopniu, można ich zakwalifikować do osób dwujęzycznych. Istotnym kryterium przy klasyfikacji dwujęzyczności jest według mnie poziom opanowania języka, a nie wiek, kontekst językowy czy warunki przyswajania języka. $\mathrm{Z}$ tego powodu interesuje mnie rezultat, a nie okoliczności przyswajania języka drugiego czy jego przebieg. Wobec tego za osobę dwujęzyczną uważam taką, która rozumie wszystkie wypowiedzi w języku drugim i potrafi poprawnie formułować skomplikowane i nigdy wcześniej niesłyszane zdania. Zakładam, że w tego typu dwujęzyczności wykształciły się z biegiem czasu dwa oddzielne leksykony mentalne, osobne dla każdego języka, które wprawdzie dalej są ze sobą powiązane, mają jednak bezpośredni dostęp do wspólnego systemu pojęć (I. Legutko-Marszałek 2007).

Grupa pierwsza badanych składała się z 40 studentów I roku germanistyki. W ciągu 1,5 godziny studenci przetłumaczyli 31 zdań tekstu. Z 40 prac wybranych zostało losowo 20, które poddane były analizie. Wszyscy studenci mieli po 20 lat. Grupa druga składała się ze studentów V roku germanistyki i liczyła również 40 osób. Do analizy wylosowanych zostało 20 prac. Wszyscy studenci mieli po 25 lat. Obie grupy miały za zadanie przetłumaczyć artykuł z tygodnika „Spiegel” (38/2005) pt. „Brüderlich teilen”. Przez wzgląd na studentów pierwszego roku thumaczenie odbywało się wyłącznie z języka niemieckiego na język polski. Tekst dotyczył tematyki polskiej, gdyż w innym przypadku nieprawidłowe zidentyfikowanie struktury pojęciowej mogłoby być spowodowane nieznajomością realiów. Wszyscy badani studenci nauczyli się języka niemieckiego w Polsce w warunkach szkolnych, a więc mamy tu do czynienia z planowanym procesem uczenia języka obcego. W trakcie studiów germanistyki język niemiecki stał się narzędziem zdobywania wiedzy z zakresu lingwistyki, czyli przejął funkcję języka pierwszego. Obok zdobywania wiedzy specjalistycznej ćwiczona była w dalszym ciągu sprawność językowa oraz dodatkowo tłumaczeniowa.

Przedstawione w mojej pracy przykłady przetłumaczonych przez studentów zdań potwierdziły przypuszczenia, że studenci pierwszego roku germanistyki nie odnoszą się podczas tłumaczenia do struktury pojęciowej. Przy wspólnym dla obu języków leksykonie mentalnym jednostki leksykalne języka niemieckiego nie mają bezpośredniego dostępu do reprezentacji wiedzy, tylko są silnie powiązane z jednostkami języka polskiego, co sprawia, że zamiast pojęć automatycznie aktywują polskie ekwiwalenty. 
W takiej sytuacji proces przetwarzania odbywa się na płaszczyźnie językowej. Studenci nie robili wprawdzie typowych błędów interferencyjnych, gdyż są nauczeni, że mają skłonność do przenoszenia reguł gramatycznych z języka ojczystego na język obcy, dlatego zwracają uwagę na tego typu błędy, jednakże koherentne tłumaczenie sprawia im jeszcze duże kłopoty. W tej grupie badanych mamy do czynienia z prawie identycznymi wersjami, które są dalekie od prawidłowego tłumaczenia. Zdania tłumaczone są zazwyczaj słowo w słowo, tzn. jednostki języka niemieckiego są po prostu zastępowane przez ekwiwalenty w języku polskim. Kontekst sytuacyjny jest pomijany, co prowadzi do tego, że często wybierane jest niewłaściwe znaczenie. Studenci pierwszego roku nie potrafią wychwycić sformułowań użytych w sensie przenośnym, w związku z czym struktura pojęciowa nie może być poprawnie odczytana.

Drugą grupę badanych cechowała już wysoka kompetencja językowa, a oprócz tego specjalistyczna wiedza z zakresu lingwistyki. Po 4,5 roku intensywnej nauki można spokojnie powiedzieć, że proces nauki języka jest w większym stopniu zakończony i wykształciła się również umiejętność tłumaczeniowa oraz tzw. ,wyczucie językowe“. Studenci piątego roku dysponują już dwoma oddzielnymi leksykonami mentalnymi dla obu języków, tak że jednostki leksykalne języka niemieckiego nie aktywują pojęć za pośrednictwem jednostek języka polskiego, tylko mają bezpośredni dostęp do systemu reprezentacji wiedzy. Umożliwia to odniesienie się do struktury pojęciowej i jej właściwą identyfikację w procesie tłumaczenia. Analizując tłumaczenia studentów drugiej grupy mogłam zaobserwować, że nie trzymali się dokładnych ekwiwalentów znaczeniowych, tak jak to miało miejsce w pierwszej grupie. Studenci próbowali najpierw odgadnąć sens całego zdania, uwzględniając przy tym rodzaj tekstu, kontekst sytuacyjny oraz wiedzę językową i pozajęzykową. Studenci piątego roku są już wprawieni w tym, aby treść zdania wyrażoną w jednym języku przenieść na inny stosując środki leksykalne i reguły gramatyczne języka docelowego. Ich tłumaczenia różnią się od siebie w dużym stopniu, co świadczy o bogatym zasobie słownictwa. Ponieważ proces uczenia się języka jest prawie zakończony, błędy związane ze strukturą języka wyjściowego były rzadkością.

\section{Podsumowanie}

Po przeanalizowaniu i porównaniu tłumaczeń tekstu obu grup, można było wyciągnąć następujące wnioski. Grupa druga przetłumaczyła większą ilość tekstu, przy czym należy podkreślić, że zdania były analizowane jedynie pod kątem niezgodności struktury pojęciowej, a nie np.: pod względem stylistycznym. W grupie pierwszej w prawie każdym zdaniu były przypadki naruszenia struktury pojęciowej, podczas gdy w drugiej grupie wiele zdań zostało przetłumaczonych bezbłędnie. W zdaniach sprawiających trudności procent źle przetłumaczonych zdań był znacznie wyższy w pierwszej grupie. Przetłumaczone zdania w grupie drugiej były dobrze przemyślane, koherentne i dla czytelnika dobrze zrozumiałe, podczas gdy tłumaczenia w grupie pierwszej wydawały się pozbawione sensu i niezrozumiałe, a nawet absurdalne. Naruszenia struktury pojęciowej w grupie drugiej dotyczyły jedynie odchyleń w zakresie znaczenia, natomiast $\mathrm{w}$ grupie pierwszej proponowane były bardzo często całkowicie nieakceptowalne ekwiwalenty. W grupie pierwszej zdarzało się wiele błędów dotyczących 
morfologiczno-syntaktycznej struktury języka, podczas gdy druga grupa popełniała błędy czysto semantyczne. Oprócz tego studentom pierwszej grupy sprawiały trudności takie formy gramatyczne jak zdania podrzędne, złożenia, rekcja, przydawka rozwinięta i podobne, podczas gdy druga grupa miała jedynie niewielkie problemy z rzadko występującymi słowami i nietypowymi konstrukcjami. W prawie identycznych tłumaczeniach pierwszej grupy dominują internacjonalizmy z uwagi na zbliżone do języka polskiego brzmienie lub formę, podczas gdy thumaczenia $w$ drugiej grupie są bardzo urozmaicone.

\begin{tabular}{|c|c|c|c|c|}
\hline \multicolumn{3}{|c|}{ GRUPA 1} & \multicolumn{2}{|c|}{ GRUPA 2} \\
\hline $\begin{array}{l}\text { NUMER } \\
\text { ZDANIA }\end{array}$ & $\begin{array}{l}\text { NIEZGODNOŚĆ } \\
\text { STRUKTURY } \\
\text { POJECIOWEJ }\end{array}$ & $\begin{array}{l}\text { ZGODNOŚĆ } \\
\text { STRUKTURY } \\
\text { POJECIOWEJ }\end{array}$ & $\begin{array}{l}\text { NIEZGODNOŚĆ } \\
\text { STRUKTURY } \\
\text { POJECIOWEJ }\end{array}$ & $\begin{array}{l}\text { ZGODNOŚĆ } \\
\text { STRUKTURY } \\
\text { POJECIOWEJ }\end{array}$ \\
\hline 1 & 15 & 85 & 0 & 100 \\
\hline 2 & 90 & 10 & 41 & 59 \\
\hline 3 & 35 & 65 & 5 & 95 \\
\hline 4 & 79 & 21 & 35 & 65 \\
\hline 5 & 60 & 40 & 10 & 90 \\
\hline 6 & 30 & 70 & 10 & 90 \\
\hline 7 & 40 & 60 & 10 & 90 \\
\hline 8 & 10 & 90 & 0 & 100 \\
\hline 9 & 85 & 15 & 35 & 65 \\
\hline 10 & 5 & 95 & 0 & 100 \\
\hline 11 & 95 & 5 & 20 & 80 \\
\hline 12 & 30 & 70 & 5 & 95 \\
\hline 13 & 15 & 85 & 0 & 100 \\
\hline 14 & 60 & 40 & 20 & 80 \\
\hline 15 & 28 & 72 & 10 & 90 \\
\hline 16 & 0 & 100 & 0 & 100 \\
\hline 17 & 29 & 71 & 30 & 70 \\
\hline 18 & 93 & 7 & 5 & 95 \\
\hline 19 & 38 & 62 & 15 & 85 \\
\hline 20 & 69 & 31 & 30 & 70 \\
\hline 21 & 92 & 8 & 35 & 65 \\
\hline 22 & 67 & 33 & 20 & 80 \\
\hline 23 & 8 & 92 & 15 & 85 \\
\hline 24 & 55 & 45 & 50 & 50 \\
\hline 25 & 70 & 30 & 10 & 90 \\
\hline 26 & 0 & 100 & 0 & 100 \\
\hline 27 & 56 & 44 & 25 & 75 \\
\hline 28 & 33 & 67 & 7 & 93 \\
\hline 29 & 25 & 75 & 27 & 73 \\
\hline 30 & 50 & 50 & 20 & 80 \\
\hline 31 & 50 & 50 & 42 & 58 \\
\hline 32 & 100 & 0 & 20 & 80 \\
\hline 33 & - & - & 50 & 50 \\
\hline 34 & - & - & 22 & 78 \\
\hline 35 & - & - & 0 & 100 \\
\hline 36 & - & - & 50 & 50 \\
\hline 37 & - & - & 0 & 100 \\
\hline 38 & - & - & 0 & 100 \\
\hline 39 & - & - & 0 & 100 \\
\hline 40 & - & - & 67 & 33 \\
\hline 41 & - & - & 0 & 100 \\
\hline 42 & - & - & 67 & 33 \\
\hline 43 & - & - & 0 & 100 \\
\hline
\end{tabular}

Tabela 1. Wyniki badań dekodowania struktury pojęciowej przettumaczonego tekstu (I. Legutko-Marszałek 2016: 232-233).

W powyższej tabeli zrobiłam zestawienie wyników thumaczenia obu grup. Od razu widać, że w grupie drugiej przeważa liczba poprawnie przetłumaczonych 
zdań, natomiast w grupie pierwszej uzależnione jest to od złożoności konstrukcji zdaniowych (w miarę bezbłędnie tłumaczone były wyłącznie proste zdania). W grupie drugiej było wiele przypadków stuprocentowej poprawności, tzn. wszyscy studenci uchwycili poprawnie strukturę pojęciową, i żadnego przypadku, w którym struktura pojęciowa naruszona by była przez wszystkich. W grupie pierwszej natomiast było stosunkowo wiele przypadków naruszenia struktury pojęciowej i nawet jeden, w którym struktura pojęciowa nie została właściwie zinterpretowana przez żadnego studenta. Wyniki moich badań sugerują, że dopóki jednostki leksykalne języka rodzimego i obcego są silnie ze sobą powiązane we wspólnym leksykonie, nie jest możliwe prawidłowe tłumaczenie. Studenci I roku germanistyki tłumaczyli tekst w ten sposób, że słowa języka niemieckiego zastępowali wprost ekwiwalentami języka polskiego bez odniesienia się do struktury pojęciowej. Natomiast studenci V roku odnosili się do płaszczyzny pozajęzykowej, uwzględniali kontekst $\mathrm{i}$ inferencje a ich tłumaczenia były logiczne i spójne. Z tego wynika, że umiejętność tłumaczenia zależy od organizacji leksykonów mentalnych. Dopiero dwa niezależne od siebie leksykony umożliwiają bezpośredni dostęp jednostek leksykalnych do pojęć.

\section{Bibliografia}

Ackermann, H. (2008), Cerebral contributions to speech production and speech perception: psycholinguistic and neurobiological perspectives, (w:), Trends in Neurosciences" 31, 265-272.

Binder, J.R./ J.A. Frost / T.A. Hammeke/ R.W. Cox/ S.M. Rao/ T. Prieto (1997), Human brain language areas identified by functional magnetic resonance imaging, (w:) ,Journal of Neuroscience” 17, 353-362.

Booth, J.R. / L. Wood/ D. Lu/ J.C. Houk/ T. Bitan (2007), The role of the basal ganglia and cerebellum in language processing, (w:) „Brain Research” 1133, 136-144.

Bottini, G./ R. Corcoran/ R. Sterzi/ E. Paulesu/ P. Schenone/ P. Scarpa/ R.S. Frackowiak/ C.D. Frith (1994), The role of the right hemisphere in the interpretation of figurative aspects of language. A PET-activation study, (w:) „Brain” 117, 1241-1253.

Cieślicka, A.B./ R.R. Heredia (2011), Hemispheric asymmetries in processing L1 and L2 idioms: Effects of salience and context, (w:) „Brain and Language” 116, 136150.

Coulson, S./ C. Lovett (2004), Handedness, hemispheric asymmetries, and joke comprehension, (w:) „Cognitive Brain Research” 19, 275-288.

Coulson, S./ C. van Petten (2002), Conceptual integration and metaphor: an eventrelated potential study, (w:) „Memory and Cognition” 30, 958-968.

Damasio, H./ D. Tranel/ T. Grabowski/ R. Adolphs/ A.R. Damasio (2004), Neural systems behind word and concept retrieval, (w:) „Cognition” 92, 179-229.

Friederici, A.D. (2002), Towards a neural basis of auditory sentence processing, (w:) „Trends in Cognitive Sciences” 6, 78-84.

Friederici, A.D./ K. Alter (2004), Lateralization of auditory language functions: a dynamic dual pathway model, (w:) „Brain and Language” 89, 267-276. 
Friederici, A.D./ J. Bahlmann/ S. Heim/ R.I. Schubotz/ A. Anwander (2006), The brain differentiates human and non-human grammars: functional localization and structural connectivity, (w:) „Proceedings of the National Academy of Sciences USA" 103, 2458-2463.

Friederici, A.D./ S.A. Kotz (2003), The brain basis of syntactic processes: functional imaging and lesion studies, (w:) „Neuroimage” 20, Suppl. 1, 8-17.

Gadenne, V. (1996), Bewusstsein, Kognition und Gehirn. Einführung in die Psychologie des Bewusstseins. Bern.

Johnson, M.D./ G.A. Ojemann (2000), The role of the human thalamus in language and memory: evidence from electrophysiological studies, (w:) „Brain and Cognition" 42, 218-230.

Kotz, S.A./ M. Schwartze/ M. Schmidt-Kassow (2009), Non-motor basal ganglia functions: a review and proposal for a model of sensory predictability in auditory language perception, (w:) „Cortex” 45, 982-990.

Kupsch-Losereit, S. (1997), Übersetzen: ein integrativ-konstruktiver Verstehens- und Produktions-prozess, (w:) H.W. Drescher (red.), Transfer. Übersetzen - Dolmetschen - Interkulturalität. Frankfurt a. M.

Legtuko-Marszałek, I. (2006), Zum Status eines mentalen Lexikons bei einem bilingualen Sprecher, (w:) „Glottodidactica. An International Journal of Applied Linguistics" 22, 59-71.

Legtuko-Marszałek, I. (2007), Die Herausbildung zweier nach Sprachen getrennten mentalen Lexika im Prozess der Fremdsprachaneignung, (w:) „Studia Niemcoznawcze" 24, $501-509$.

Legtuko-Marszałek, I. (2007a), Die Unterscheidung zwischen Bedeutungen und Begriffen in Anbetracht des Bilingualismus, (w:) „Studia Germanica Gedanensia” $15,163-168$.

Legutko-Marszałek, I. (2016), Übersetzen als komplexer, kognitiv bedingter, sowohl das sprachliche Wissen in zwei Sprachen als auch das sprachunabhängige begriffliche Wissen integrierender Prozess. Gdańsk.

Maess, B./ S. Koelsch/ T.C. Gunter/ A.D. Friederici (2001), Musical syntax is processed in Broca's area: an MEG study, (w:) „Nature Neuroscience” 4, 540-545.

Newman, S.D. / M.A. Just/ T.A. Keller/ J. Roth/ P.A. Carpenter (2003), Differential effects of syntactic and semantic processing on the subregions of Broca's area, (w:) „Cognitive Brain Research” 16, 297-307.

Price, C.J. (2000), The anatomy of language: contributions from functional neuroimaging, (w:) ,Journal of Anatomy” 197, 335-359.

Pulvermüller, F. / L. Fadiga (2010), Active perception: sensorimotor circuits as a cortical basis for language, (w:) „Nature Reviews Neuroscience” 11, 351-360.

Rickheit, G. / H. Strohner (1999), Textverarbeitung: Von der Proposition zur Situation, (w:) A. Friederici (red.), Sprachrezeption. Göttingen, 271-306.

Rickheit, G./ S. Weiss/ H.J. Eikmeyer (2010), Kognitive Linguistik. Theorien, Modelle, Methoden. Tübingen.

Rösler, F. (2011), Psychophysiologie der Kognition. Eine Einführung in die kognitive Neurowissenschaft. Heidelberg. 
Sahin, N.T./ S. Pinker/ S.S. Cash/ D. Schomer/ E. Halgren (2009), Sequential processing of lexical, grammatical, and phonological information within Broca's area, (w:) ,Science” 326, 445-449.

Sammler, D./ S. Koelsch/ T. Ball/ A. Brandt/ C.E. Elger/ A.D. Friederici (2009), Overlap of musical and linguistic syntax processing: intracranial ERP evidence, (w:) „NY Academy of Sciences” 1169, 494-498.

Schmidt, G.L./ C.A. Seger (2009), Neural correlates of metaphor processing: the roles of figurativeness, familiarity and difficulty, (w:) „Brain and Cognition” 71, 375-386.

St. George, M./ M. Kutas/ A. Martines/ M.I. Sereno (1999), Semantic integration in reading: Engagement of the right hemisphere during discourse processing, (w:) „Brain” 122, 1317-1325.

Stowe, L.A./ M. Haverkort/ F. Zwarts (2005), Rethinking the neurobiological basis of language, (w:) „Lingua” 115, 997-1042.

Thomson, C.K./ B. Bonakdarpour/ S.F. Fix (2010), Neural mechanisms of verb argument structure processing in agrammatic aphasic and healthy age-matched listeners, (w:) ,Journal of Cognitive Neuroscience” 22, 1993-2011.

Ullman, M.T. (2006), Is Broca's area part of basal ganglia thalamocortical circuit?, (w:) „Cortex“ 42, 480-485.

Wahl, M. / F. Marzinzik/ A.D. Fiederici/ A. Hahne/ A. Kupsch/ G.H. Schneider/ D. Saddy/ G. Curio/ F. Klostermann (2008), The human thalamus processes syntactic and semantic language violations, (w:) „Neuron” 59, 695-707.

Wallesch, C.W. (2006), Sprache, (w:) H.-O. Karnath/ P. Trier (red.), Neuropsychologie. Berlin. 